\title{
THE
}

8-7-2019

\section{Minimized Metal Dissolution from High-Energy Nickel Cobalt Manganese Oxide Cathodes with Al203 Coating and Its Effects on Electrolyte Decomposition on Graphite Anodes}

Sunhyung Jurng

Satu Kriistina Heiskanen

KWD Kaveendi Chandrasiri

Maheeka Yapa Abeywardana

Brett L. Lucht

University of Rhode Island, blucht@uri.edu

Follow this and additional works at: https://digitalcommons.uri.edu/chm_facpubs

Creative Commons License

\section{(c) (i)}

This work is licensed under a Creative Commons Attribution 4.0 License.

\section{Citation/Publisher Attribution}

Sunhyung Jurng et al 2019 J. Electrochem. Soc. 166 A2721. https://doi-org.uri.idm.oclc.org/10.1149/ 2.0101913jes 
OPEN ACCESS

Minimized Metal Dissolution from High-Energy Nickel Cobalt Manganese Oxide Cathodes with $\mathrm{Al}_{2} \mathrm{O}_{3}$ Coating and Its Effects on Electrolyte Decomposition on Graphite Anodes

To cite this article: Sunhyung Jurng et al 2019 J. Electrochem. Soc. 166 A2721

View the article online for updates and enhancements. 


\title{
HeS \\ Minimized Metal Dissolution from High-Energy Nickel Cobalt Manganese Oxide Cathodes with $\mathrm{Al}_{2} \mathrm{O}_{3}$ Coating and Its Effects on Electrolyte Decomposition on Graphite Anodes
}

\author{
Sunhyung Jurng, $\odot$ Satu Kristiina Heiskanen, $(\bullet *$ K. W. D. Kaveendi Chandrasiri, \\ Maheeka Yapa Abeywardana, and Brett L. Lucht $\mathbb{1}{ }^{* *, z}$
}

Department of Chemistry, University of Rhode Island, Kingston, Rhode Island 02881, USA

\begin{abstract}
High-energy nickel cobalt manganese oxides have been studied intensively as cathode materials for lithium-ion batteries. However, several hurdles need to be overcome to adopt these cathodes in commercial lithium-ion batteries. Herein, aluminum oxide $\left(\mathrm{Al}_{2} \mathrm{O}_{3}\right)$ coating was applied to high-energy nickel cobalt manganese oxides (HE-NCM, $\mathrm{Li}_{1.33} \mathrm{Ni}_{0.27} \mathrm{Co}_{0.13} \mathrm{Mn}_{0.60} \mathrm{O}_{2+\mathrm{d}}$ ) by atomic layer deposition (ALD) and its effects on HE-NCM/graphite full cells were investigated. HE-NCM/graphite full cells have better cycling performance and efficiency when $\mathrm{HE}-\mathrm{NCM}$ is coated with $\mathrm{Al}_{2} \mathrm{O}_{3}$. ICP-MS measurements show that the $\mathrm{Al}_{2} \mathrm{O}_{3}$ coating can effectively prevent transition metal dissolution from HE-NCM. XPS and FT-IR analysis suggests that the surface film on HE-NCM cathodes does not change significantly with the $\mathrm{Al}_{2} \mathrm{O}_{3}$ coating even after 50 cycles, however the surface film on graphite anodes shows a significant change. The resistance of graphite electrodes cycled with the uncoated HE-NCM is higher than that of graphite electrodes cycled with the $\mathrm{Al}_{2} \mathrm{O}_{3}$-coated $\mathrm{HE}-\mathrm{NCM}$ due to the increased SEI thickness. The improved cycling performance of HE-NCM/graphite cells with $\mathrm{Al}_{2} \mathrm{O}_{3}$ coating can be attributed to the minimized resistance increase on graphite as well as the suppression of cathode active material loss.

(C) The Author(s) 2019. Published by ECS. This is an open access article distributed under the terms of the Creative Commons Attribution 4.0 License (CC BY, http://creativecommons.org/licenses/by/4.0/), which permits unrestricted reuse of the work in any medium, provided the original work is properly cited. [DOI: $10.1149 / 2.0101913$ jes]

(cc) BY
\end{abstract}

Manuscript submitted June 12, 2019; revised manuscript received July 29, 2019. Published August 7, 2019.

Because of their high capacity $\left(>240 \mathrm{mAh} \mathrm{g}^{-1}\right)$, high-energy nickel cobalt manganese oxides (usually called, "Lithium-rich layered oxides") are considered as promising cathode candidates for the nextgeneration lithium-ion batteries. ${ }^{1-3}$ However, several hurdles need to be overcome to adopt these cathodes into commercial lithium-ion batteries. The undesired transition metal dissolution from these cathodes is one of the key challenges, since it not only damages the structural stability of cathodes but also alters the composition of solid electrolyte interphase (SEI) on the surface of anodes. ${ }^{4-7}$ The previous report about the capacity recovery of NCM cathodes collected from full cells suggests the deterioration of anode is the main cause of full cell degradation. ${ }^{8}$

Although transition metal dissolution from various cathodes has been studied extensively, ${ }^{9-13}$ the effect of transition metal dissolution on the SEI layer of anode has not been well-established due to the large number of different materials investigated. Dissolved transition metal ions accumulate on the anode, where they induce additional side reactions of electrolyte, continuous SEI growth and further the loss of active lithium. ${ }^{6,14}$ It is reported that an electrolyte containing Mn ions generates a non-passivating SEI on the anode surface from the model experiments ${ }^{15}$ and also transition metal ions are electrochemically reduced on the surface of anode leading to metal deposition. ${ }^{16}$ The effect of transition metal ions on the composition and stability of the SEI on the anode has not been well addressed.

Surface coatings of cathode materials with various inert metal oxides including $\mathrm{Al}_{2} \mathrm{O}_{3}$ is one of the most common approach to suppress transition metal dissolution from cathodes. ${ }^{17-19} \mathrm{Al}_{2} \mathrm{O}_{3}$ coating provides a stable protection layer on the cathode surface and prevents interfacial degradation of the cathode. It has been reported that an $\mathrm{Al}_{2} \mathrm{O}_{3}$ coating can minimize transition metal dissolution from cathodes..$^{20,21}$

In this work, an $\mathrm{Al}_{2} \mathrm{O}_{3}$ coating was applied on high-energy nickel cobalt manganese oxide (HE-NCM, $\mathrm{Li}_{1.33} \mathrm{Ni}_{0.27} \mathrm{Co}_{0.13} \mathrm{Mn}_{0.60} \mathrm{O}_{2+\mathrm{d}}$ ) cathodes by atomic layer deposition (ALD) and the effect on HE$\mathrm{NCM} /$ graphite full cells were investigated. Changes in cycling performance of full cells due to the effect of transition metal dissolution on both electrodes are presented. To understand the effects of transition metal dissolution on the surface film of each electrode, both surface films were analyzed using X-ray photoelectron spectroscopy (XPS)

\footnotetext{
*Electrochemical Society Student Member

**Electrochemical Society Member.

${ }^{\text {zE} E-m a i l: ~ b l u c h t @ c h m . u r i . e d u ~}$
}

and infrared spectra with attenuated total reflectance (IR-ATR) upon cycling. A possible mechanism for degradation of HE-NCM/graphite full cells is discussed based on the findings.

\section{Experimental}

Coin cell preparation.- $-\mathrm{HE}-\mathrm{NCM}$ electrodes were prepared using a composition of $93 \mathrm{wt} \% \mathrm{HE}-\mathrm{NCM}$ (with/without $\mathrm{Al}_{2} \mathrm{O}_{3}$ coating), $3 \mathrm{wt} \%$ conductive carbon, and $4 \mathrm{wt} \%$ polyvinylidene difluoride (PVdF) binder. Each slurry was mechanically blended with N-methyl2-pyrrolidone (NMP) solvent in a nitrogen-filled glove box and pasted onto aluminum foil. Both HE-NCM powders and graphite electrodes were supplied from a commercial supplier as battery grade.

2032-type coin cells containing HE-NCM positive electrodes (13.7 mm diameter), PP/PE/PP separators (19 mm diameter, Celgard 2325) and graphite negative electrodes ( $14 \mathrm{~mm}$ diameter) were assembled in an argon glove box (M-Braun) with oxygen and water contents $<1 \mathrm{ppm}$. Both HE-NCM and graphite electrodes were punched to a specific diameter, and dried at $110^{\circ} \mathrm{C}$ under vacuum overnight before cell assembly. The average active mass loading and areal capacity of HE-NCM electrodes are $7.3 \mathrm{mg} \mathrm{cm}^{-2}$ and $1.83 \mathrm{mAh} \mathrm{cm}^{-2}$, respectively. The $\mathrm{n} / \mathrm{p}$ ratio is controlled within a range of 1.05 to 1.1 (capacity), using the $1^{\text {st }}$ charge capacity of HE-NCM and graphite (330 and $372 \mathrm{mAh} / \mathrm{g}$ ). $100 \mu \mathrm{L}$ of $1.2 \mathrm{M} \mathrm{LiPF}_{6}$ in EC:EMC is used as an electrolyte for each cell.

Electrochemical testing.-Galvanostatic cycling of HENCM/graphite cells was conducted using an Arbin BT2000 battery cycler in a constant temperature oven $\left(25^{\circ} \mathrm{C}\right)$. The cycling procedure consists of three steps; (i) $10 \mathrm{~mA} / \mathrm{g}$ within $2.0-4.8 \mathrm{~V}$ ( $1^{\mathrm{st}}$ cycle), (ii) $20 \mathrm{~mA} / \mathrm{g}$ within $2.0-4.6 \mathrm{~V}\left(2^{\text {nd }}-5^{\text {th }}\right.$ cycle $)$, and (iii) $40 \mathrm{~mA} / \mathrm{g}$ within 2.0-4.6 V (the prolonged cycle). Each current was calculated based on the active mass of HE-NCM electrode. A 6-hour rest period was also introduced at the beginning of each cycling protocol to confirm uniform wetting of all cell components.

Inductively coupled plasma mass spectrometry (ICP-MS).-An iCAP Q ICP-MS instrument (Thermo Scientific) with He KED interference reduction system was used for ICP-MS measurements. After cycling and allowing to equilibrate for 48 hours, the HE-NCM/graphite cells were disassembled in an argon glove box. Without the HE-NCM electrodes, all other cell parts were sealed in $15 \mathrm{~mL}$ centrifuge vials 
and centrifuged at 2200 RPM for 10 minutes to collect as much of the electrolyte as possible. After centrifuging, the cell parts were removed from the vial and the graphite electrodes were separately dissolved in $10 \mathrm{~mL}$ of $2 \% \mathrm{HNO}_{3}$ solution to extract metal ions from graphite. The extracted solution and collected electrolyte were combined again and filtered for the ICP-MS measurements. A three-point calibration was conducted in $2 \% \mathrm{HNO}_{3}$ before each sample set. The calibration range was from 50 to $500 \mathrm{ppm}$ for $\mathrm{Ni}$ and $\mathrm{Mn}$ and 10 to $100 \mathrm{ppm}$ for Co.

X-ray photoelectron spectroscopy (XPS)._A K-alpha spectrometer (Thermo Scientific) using $\mathrm{Al} \mathrm{K} \alpha$ radiation $(\mathrm{h} \nu=1486.6 \mathrm{eV})$ under ultra-high vacuum $\left(<1 \times 10^{-12} \mathrm{~atm}\right)$ was used for XPS measurements. The measuring spot size and pass energy were $400 \mu \mathrm{m}$ in diameter and $60 \mathrm{eV}$ for this instrument. After equilibration for 48 hours, the HE-NCM/graphite cells were disassembled in an argon glove box. Each electrode was washed with battery grade EMC, three times with $0.5 \mathrm{~mL}$ per wash, to remove the electrolyte residue, dried overnight under vacuum, and transferred in an air-free container to the XPS chamber. The PVdF $(688 \mathrm{eV})$ and LiF peaks $(685 \mathrm{eV})$ were used as reference peaks for HE-NCM and graphite to correct the binding energy scale for all spectra, respectively. Relative atomic concentrations were calculated from the integration of each XPS peak, upon consideration of respective atomic sensitivity factors. An argon flood gun was used as needed to avoid charge accumulation on samples.

Infrared spectra with attenuated total reflectance (IR-ATR).-A Bruker Tensor 27 equipped with an attenuated total reflection (ATR) system and LaDTG detector was used for IR measurements. After cycling and allowing equilibration for 48 hours, the HE-NCM/graphite cells were disassembled in an argon glove box. Each electrode was washed with battery grade EMC, dried overnight under vacuum, and transferred in a closed container to a nitrogen-filled glove box. The spectra were acquired with a resolution of $4 \mathrm{~cm}^{-1}$ and 256 scans in the nitrogen glove box. An atmospheric compensation and baseline correction were applied to all spectra.

\section{Results and Discussion}

The galvanostatic cycling performance of the HE-NCM/graphite full cells is provided in Fig. 1 with discharging capacity, normalized based on the active mass of $\mathrm{HE}-\mathrm{NCM}$. The $\mathrm{Al}_{2} \mathrm{O}_{3}$ coating on $\mathrm{HE}-\mathrm{NCM}$ clearly improves the capacity retention of HE-NCM/graphite full cells. The HE-NCM/graphite cells containing the uncoated or $\mathrm{Al}_{2} \mathrm{O}_{3}$-coated HE-NCM electrode show similar discharging capacity after the precycling step $\left(6^{\text {th }}\right.$ cycle, $\sim 240 \mathrm{mAh} / \mathrm{g}$ ), however the capacity of the cell containing uncoated HE-NCM decays faster upon prolonged cycling. This rapid decay is consistent with a loss of cyclable lithium ions during cycling when $\mathrm{HE}-\mathrm{NCM}$ is not coated with $\mathrm{Al}_{2} \mathrm{O}_{3}$. Since there is no excess lithium in the HE-NCM/graphite full cells, any lithium loss directly affects the cycling performance of the cells.

The ICP-MS results for quantification of metal dissolution provide insight into the source of cycling performance decay of HENCM/graphite cells (Fig. 2). The transition metal dissolution from the uncoated HE-NCM electrode is four times higher than the transition metal dissolution from the $\mathrm{Al}_{2} \mathrm{O}_{3}$ coated $\mathrm{HE}-\mathrm{NCM}$ electrode. This suggests that the $\mathrm{Al}_{2} \mathrm{O}_{3}$ coating stabilizes the surface structure of HENCM and prevents transition metal dissolution from HE-NCM into electrolytes. ${ }^{17,22,23}$ It is reported that transition metal dissolution from the cathode has a detrimental effect on graphite anode and overall cell performance, yet the specific mechanism is not fully established. ${ }^{24,25}$

To elaborate the effect of metal dissolution on the surface chemistry of full cells, the surface film on both HE-NCM and graphite electrodes was investigated using XPS analysis (Figs. 3-5). While the surface modification was applied to HE-NCM positive electrodes, the surface films developed on the uncoated and $\mathrm{Al}_{2} \mathrm{O}_{3}$-coated HE-NCM are very similar even after 50 cycles (Fig. 3). Before cycling (pristine, gray lines), both electrodes have strong features of PVdF in the C 1s (291 eV, Figs. 3a and 3d) and F 1s spectra (688 eV, Figs. 3c and $3 \mathrm{f}) .{ }^{26}$ In the $\mathrm{O} 1 \mathrm{~s}$ spectra, the $\mathrm{Al}_{2} \mathrm{O}_{3}$-coated HE-NCM has a dis-
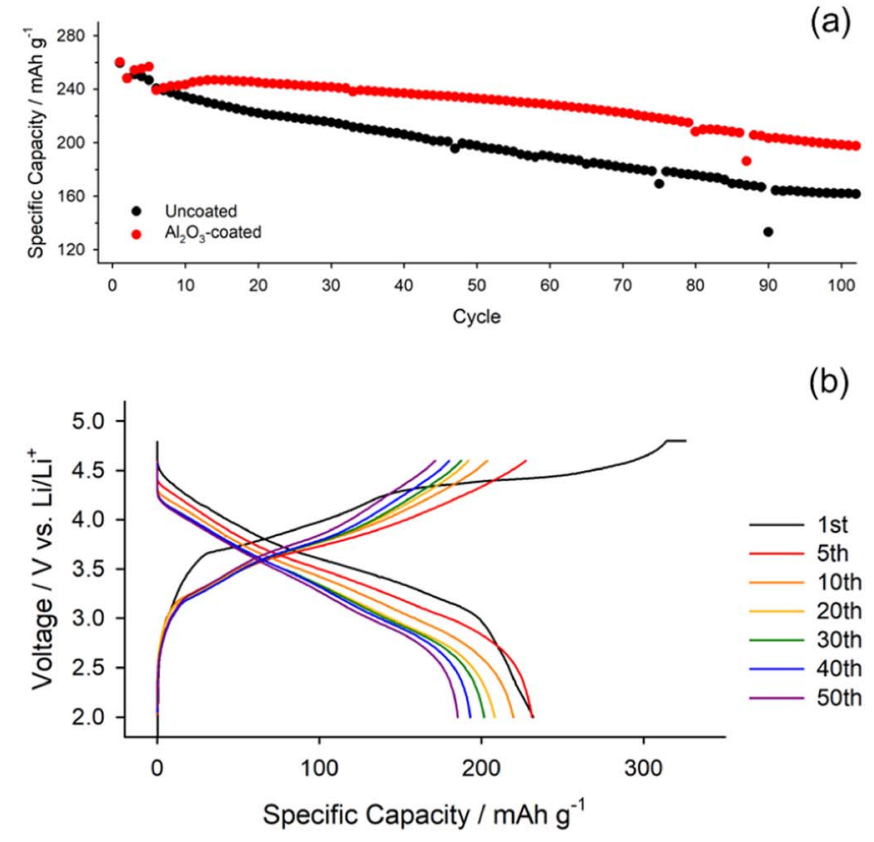

(b)

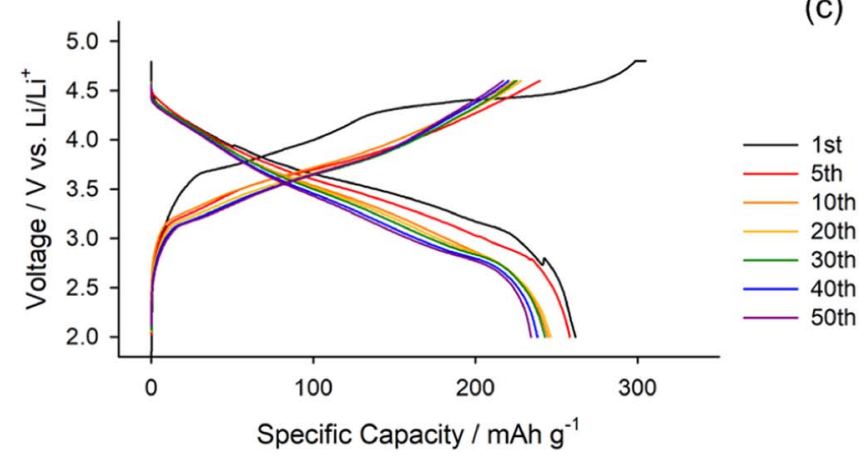

Figure 1. (a) Discharge capacity vs. cycle number and voltage profiles obtained from HE-NCM/Graphite full cells containing (b) the uncoated and (c) $\mathrm{Al}_{2} \mathrm{O}_{3}$-coated HE-NCM electrodes. The capacity was calculated based on the active mass of HE-NCM electrodes.

tinct shoulder around $531.8 \mathrm{eV}$ (Fig. 3e), suggested to come from the $\mathrm{Al}_{2} \mathrm{O}_{3}$ coating, consistent with the presence of the corresponding peak in the $\mathrm{Al} 2 \mathrm{p}$ spectrum at $74 \mathrm{eV}$ (Fig. $3 \mathrm{~h}$ ). ${ }^{26,27}$ After cycling, C-O $(533.5 \mathrm{eV})$ and $\mathrm{C}=\mathrm{O}(531.8 \mathrm{eV})$ peaks in the $\mathrm{O} 1 \mathrm{~s}$ spectra grow on both electrodes, ${ }^{28-30}$ indicating the decomposition of carbonate solvents (Figs. $3 \mathrm{~b}$ and $3 \mathrm{e}$ ). These peaks are relatively greater intensity on the uncoated HE-NCM, implying more electrolyte decomposition

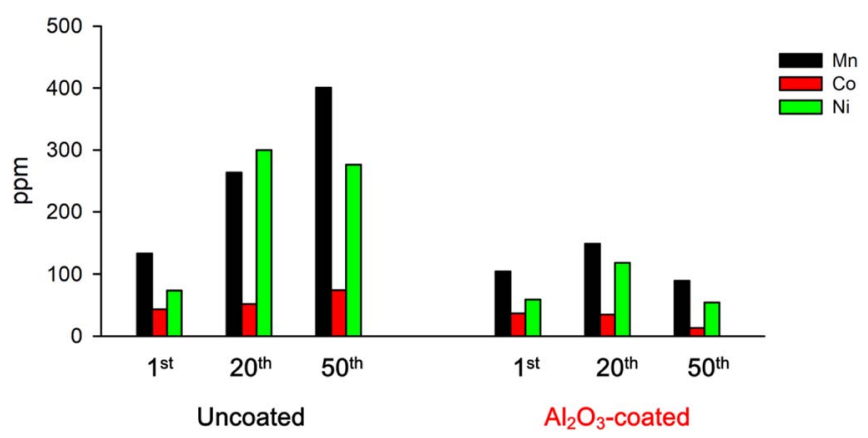

Figure 2. ICP-MS results obtained from HE-NCM/Graphite full cells containing the uncoated and $\mathrm{Al}_{2} \mathrm{O}_{3}$-coated $\mathrm{HE}-\mathrm{NCM}$ electrodes. 


\section{HE-NCM}
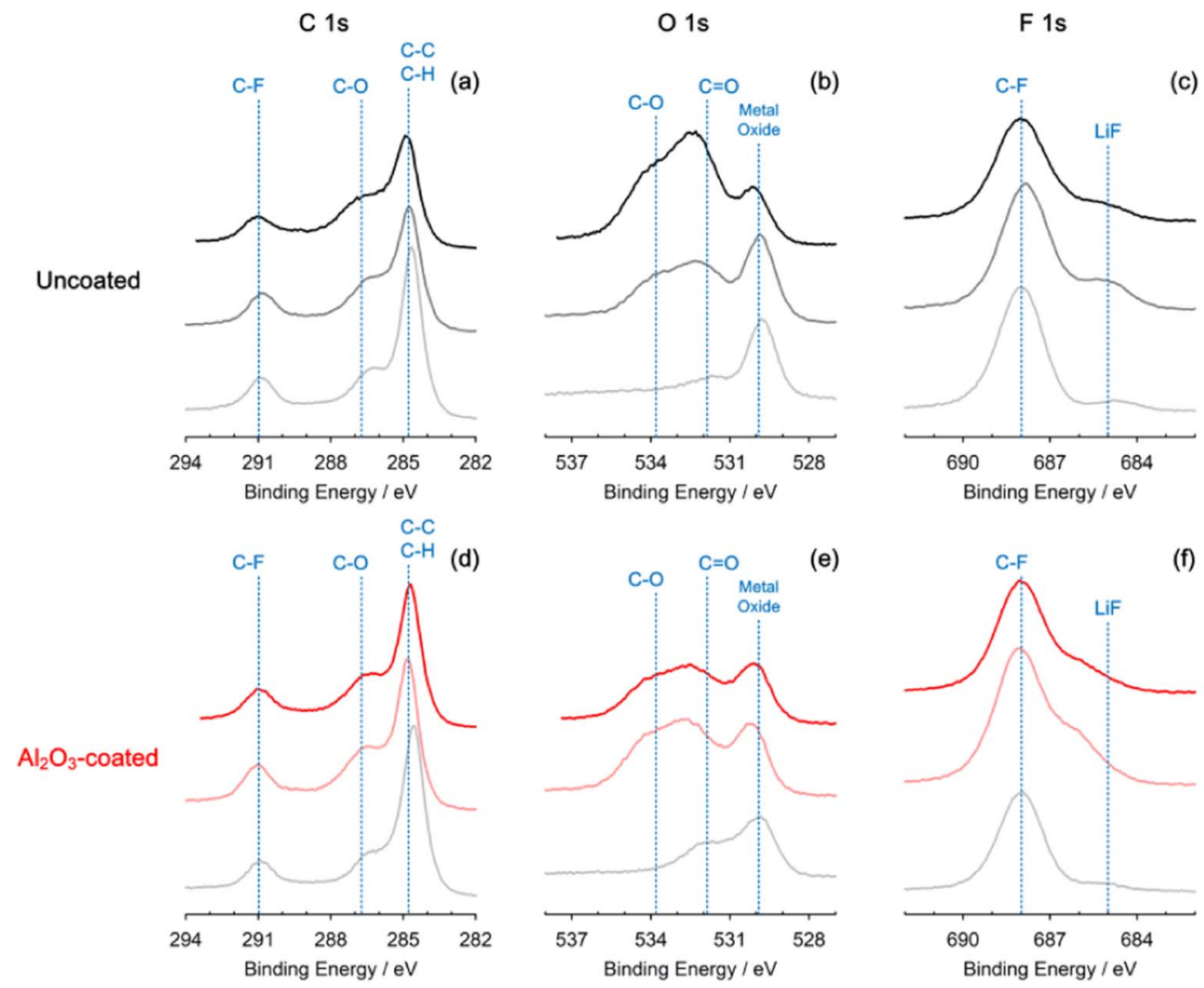

Al $2 p$ (pristine)

(c)

(g)

Figure 3. XPS spectra obtained from the uncoated and $\mathrm{Al}_{2} \mathrm{O}_{3}$-coated $\mathrm{HE}-\mathrm{NCM}$ electrodes collected from HE-NCM/Graphite full cells

\section{Graphite}

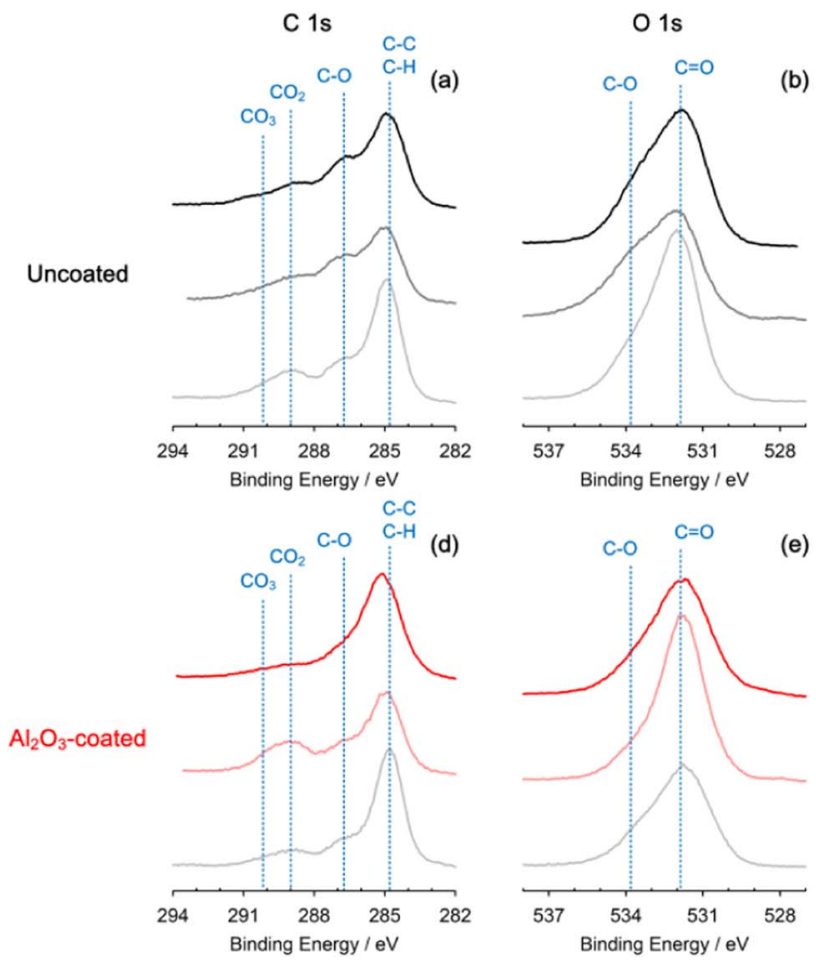

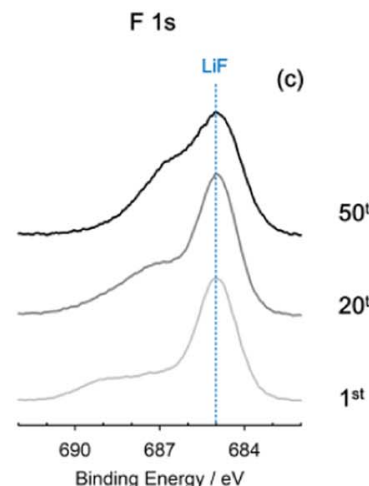

e)

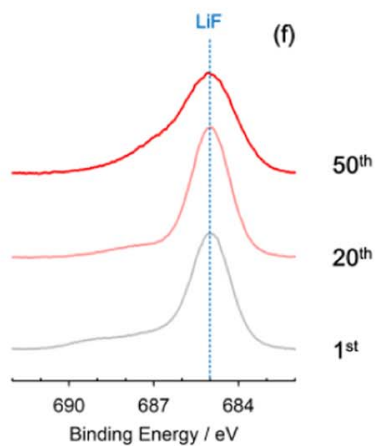

P 2p

(g)

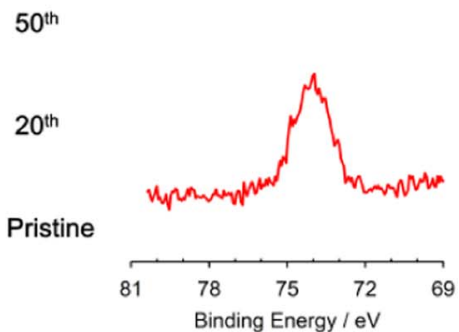

(f) 
(a) HE-NCM

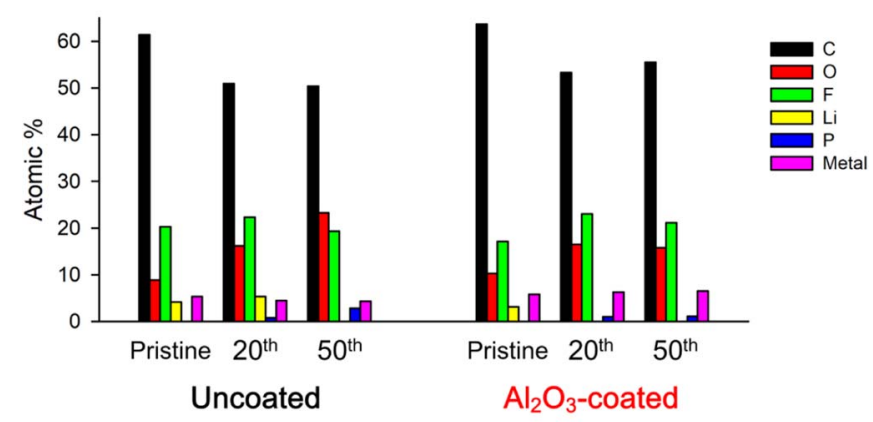

(b) Graphite

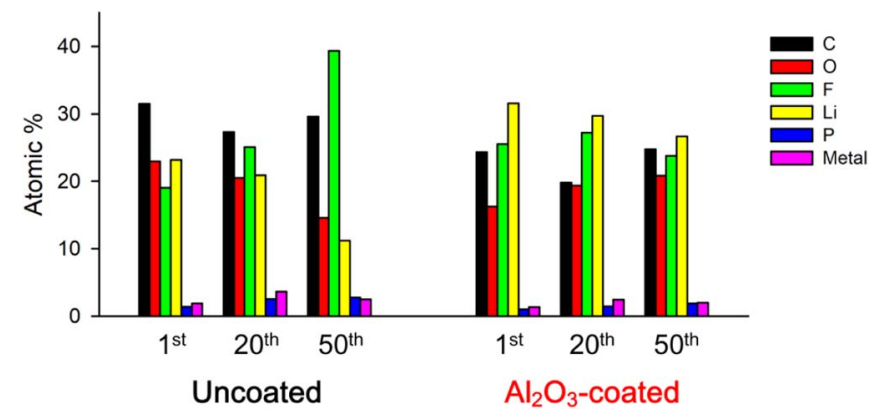

Figure 5. Corresponding relative atomic concentrations from XPS spectra obtained from the HE-NCM electrodes and graphite electrodes. The total concentration of $\mathrm{Ni}, \mathrm{Mn}$ and $\mathrm{Co}$ is presented as metal concentration.

has occurred on the electrode surface. A broad peak characteristic of $\mathrm{Li}_{\mathrm{x}} \mathrm{PF}_{\mathrm{y}} \mathrm{O}_{\mathrm{z}}$ (around 686-687 eV) and a small LiF peak $(685 \mathrm{eV})$ are also observed on both electrodes after cycling (Figs. $3 \mathrm{c}$ and $3 \mathrm{f}$ ). ${ }^{26}$ Although these changes provide evidence for electrolyte decomposition on $\mathrm{HE}$ -
NCM positive electrodes, it is suggested the surface of HE-NCM is not completely passivated upon prolonged electrochemical cycling. Even after 50 cycles, the peaks characteristic of $\mathrm{PVdF}$ and bulk metal oxide $(530 \mathrm{eV})$ can be observed from the HE-NCM surface. ${ }^{26,31}$ Further, the relative atomic concentrations calculated from the corresponding XPS spectra of HE-NCM (Fig. 5a), illustrate that the surface of HE-NCM electrode does not change significantly upon cycling.

Interestingly, the surface chemistry of graphite appears to be more altered by the $\mathrm{Al}_{2} \mathrm{O}_{3}$ coating on HE-NCM than the surface of the HENCM itself (Fig. 4 and Fig. 5b). The relative atomic concentration of graphite changes notably upon cycling (Fig. 5b). The relative concentration of fluorine increases significantly on the surface of graphite when cycled with the uncoated HE-NCM. However, the surface of graphite cycled with the $\mathrm{Al}_{2} \mathrm{O}_{3}$-coated $\mathrm{HE}-\mathrm{NCM}$ is relatively stable over the first 50 cycles. While the relative atomic concentrations show a large difference, the XPS spectra from two graphite electrodes contain similar peaks (Fig. 4). This denotes that the types of electrolyte decomposition products do not change, however, the relative ratio of the different decomposition products on the graphite surface are altered. Both graphite electrodes have $\mathrm{C}-\mathrm{O}$ and $\mathrm{C}=\mathrm{O}$ features $(286.8$ \& $289 \mathrm{eV}$ in the $\mathrm{C} 1 \mathrm{~s}$ and $531.8 \& 533.5 \mathrm{eV}$ in $\mathrm{O} 1 \mathrm{~s}$ spectra) as well as a $\mathrm{LiF}$ peak $(685 \mathrm{eV}$ in the $\mathrm{F} 1 \mathrm{~s}) .{ }^{28-30}$ The $\mathrm{F} 1 \mathrm{~s}$ spectrum for the graphite electrode cycled with the uncoated HE-NCM contains an intense peak characteristic of $\mathrm{Li}_{x} \mathrm{PF}_{\mathrm{y}} \mathrm{O}_{\mathrm{z}}(686-687 \mathrm{eV}),{ }^{26}$ which increases upon prolonged cycling. The $\mathrm{P} 2 \mathrm{p}$ spectra also shows broad peaks characteristic of $\mathrm{Li}_{\mathrm{x}} \mathrm{PF}_{\mathrm{y}} \mathrm{O}_{\mathrm{z}}(134-135 \mathrm{eV})$ and $\mathrm{LiPF}_{6}(136-138 \mathrm{eV}){ }^{32,33}$ Overall, more $\mathrm{LiPF}_{6}$ salt decomposition occurs on the surface of graphite when cycled with the uncoated HE-NCM.

The IR-ATR spectra for both HE-NCM and graphite electrodes after 50 cycles are provided in Fig. 6. As with the XPS results described above, the IR spectra for the uncoated and $\mathrm{Al}_{2} \mathrm{O}_{3}$-coated HE-NCM after 50 cycles are very similar (Fig. 6a). Most of the features in the spectra of both HE-NCM electrodes are attributed to PVdF binder (a $800-1300 \mathrm{~cm}^{-1}$ region, peaks at $1400 \mathrm{~cm}^{-1}$ and $1740 \mathrm{~cm}^{-1}$ ), ${ }^{34}$ supporting the XPS result for HE-NCM electrodes (Fig. 3). However, the IR spectra for the graphite electrodes cycled with the uncoated and $\mathrm{Al}_{2} \mathrm{O}_{3}$-coated HE-NCM reveal some notable differences

\section{(a) HE-NCM}

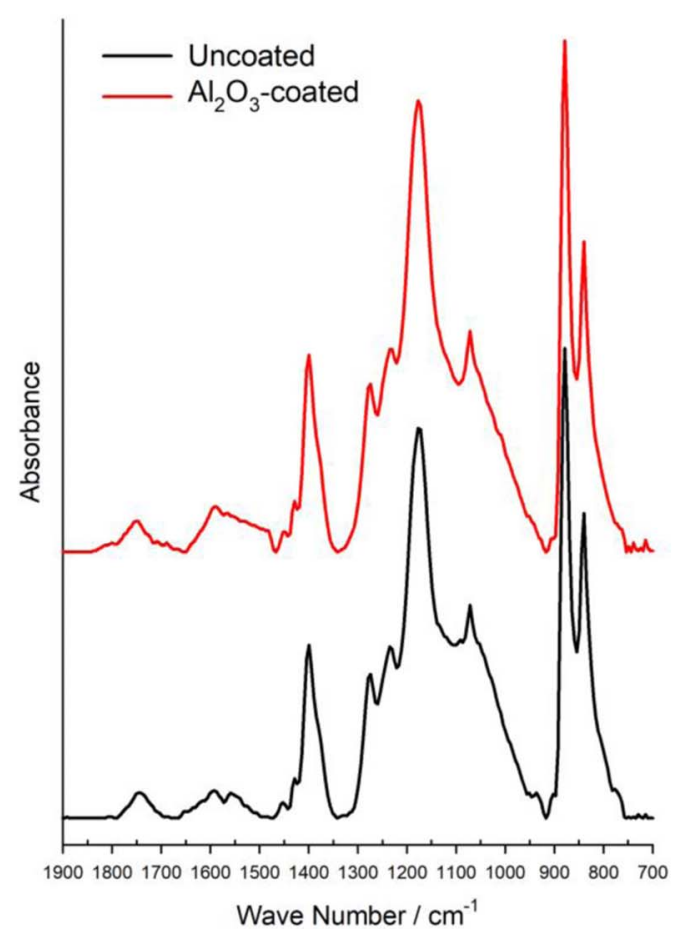

\section{(b) Graphite}

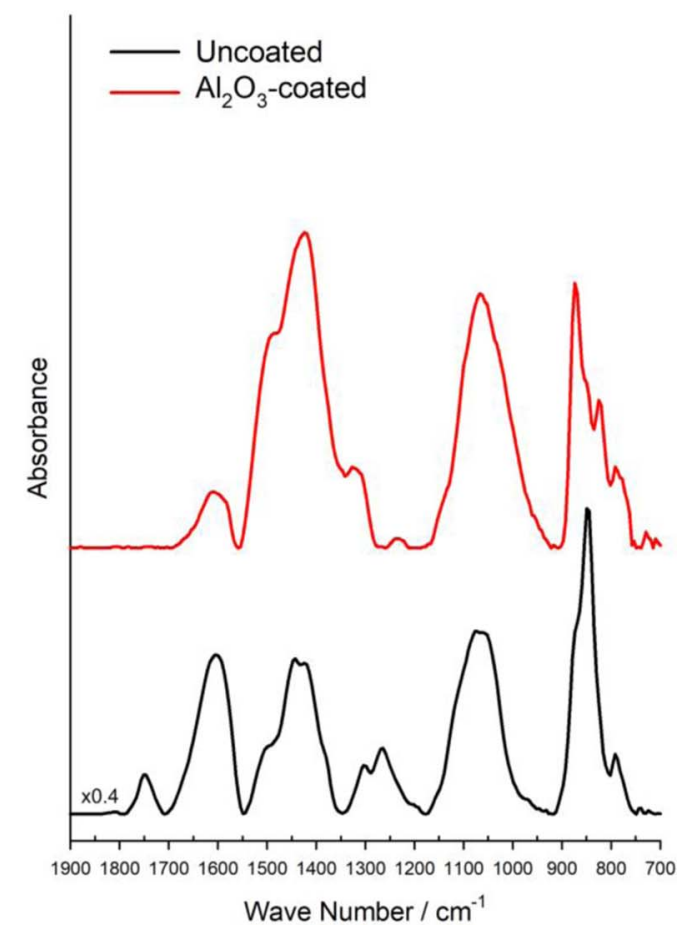

Figure 6. IR-ATR spectra obtained from the (a) HE-NCM electrodes and (b) graphite electrodes after 50 cycles. 

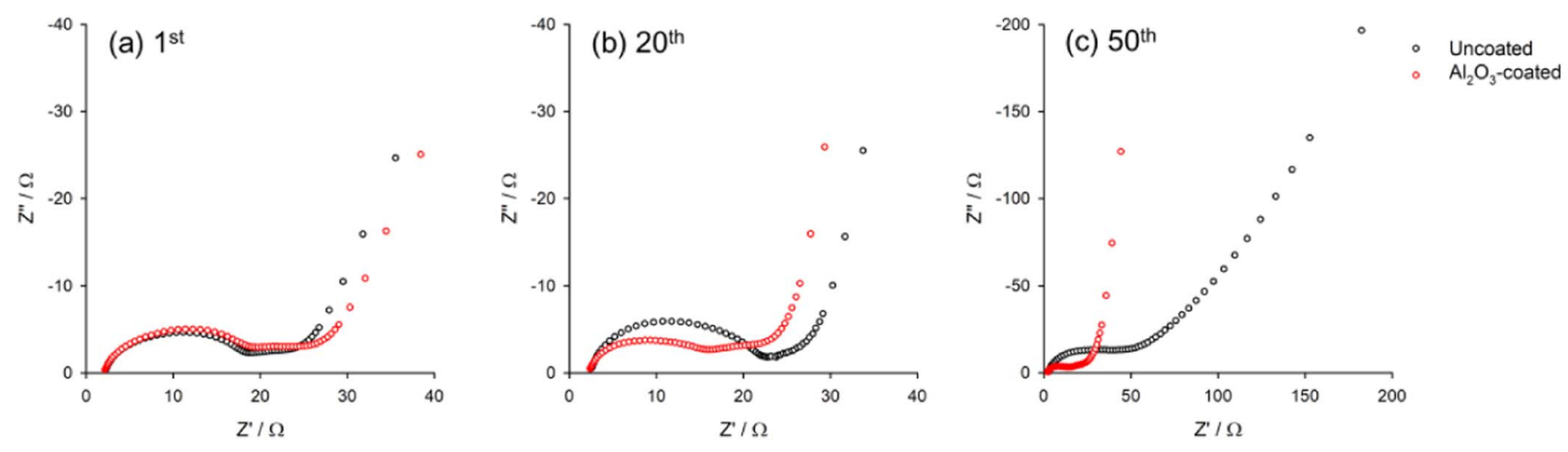

Figure 7. The Nyquist plots obtained from graphite/graphite symmetric cells, in which graphite electrodes were collected from two identical HE-NCM/Graphite full cells containing the uncoated and $\mathrm{Al}_{2} \mathrm{O}_{3}$-coated $\mathrm{HE}-\mathrm{NCM}$ electrodes.

(Fig. 6b). While both spectra contain peaks characteristic of lithium ethylene dicarbonate (LEDC, 1652, 1400, 1315, 1100, and $825 \mathrm{~cm}^{-1}$ ) and $\mathrm{Li}_{2} \mathrm{CO}_{3}\left(1490,1433\right.$ and $\left.875 \mathrm{~cm}^{-1}\right),{ }^{35-37}$ the graphite cycled with the uncoated HE-NCM contains additional features of oligo or poly carbonate $\left(1750,1300\right.$, and $\left.1260 \mathrm{~cm}^{-1}\right){ }^{38}$ The oligo carbonates are likely generated on the uncoated cathode surface from electrolyte oxidation and then cross over to the anode where they are reduced and deposited. Consistent with the XPS results (Fig. 4g), a strong peak is observed at $840 \mathrm{~cm}^{-1}$ on the graphite cycled with the uncoated HE$\mathrm{NCM}$ which is characteristic of the P-F bond ${ }^{39}$ suggesting the presence of $\mathrm{Li}_{x} \mathrm{PF}_{\mathrm{y}} \mathrm{O}_{\mathrm{z}}$ and residual $\mathrm{LiPF}_{6}$. This further supports $\mathrm{LiPF}_{6}$ salt decomposition is a major component of the SEI evolution on graphite when it is cycled with the uncoated HE-NCM. ${ }^{40}$

With the above surface analysis results (XPS and IR), it can be concluded that metal dissolution from HE-NCM leads to the additional electrolyte decomposition on the surface of graphite. To further understand the effect on the degradation of graphite, the resistance of graphite was measured using the electrochemical impedance spectroscopy (EIS). In Fig. 7, Nyquist plots of graphite/graphite symmetric cells, in which graphite electrodes were collected from HE$\mathrm{NCM} /$ graphite cells are provided. After the $1^{\text {st }}$ cycle, the resistance of graphite electrodes is almost identical whether they were cycled with the uncoated or $\mathrm{Al}_{2} \mathrm{O}_{3}$-coated $\mathrm{HE}-\mathrm{NCM}$ electrodes. Upon the cycling, however, the resistance of graphite cycled with the uncoated HE-NCM has increased significantly while the one of graphite cycled with the $\mathrm{Al}_{2} \mathrm{O}_{3}$-coated HE-NCM is stabilized. Therefore, it is reasonable to infer that metal dissolution from HE-NCM eventually increases the resistance of graphite and further causes the full cell degradation.

\section{Conclusions}

The influence of aluminum oxide $\left(\mathrm{Al}_{2} \mathrm{O}_{3}\right)$ coating on to high-energy nickel cobalt manganese oxides (HE-NCM, $\left.\mathrm{Li}_{1.33} \mathrm{Ni}_{0.27} \mathrm{Co}_{0.13} \mathrm{Mn}_{0.60} \mathrm{O}_{2+\mathrm{d}}\right)$ has been investigated in $\mathrm{HE}-$ $\mathrm{NCM} /$ graphite full cells. $\mathrm{Al}_{2} \mathrm{O}_{3}$ coating on HE-NCM improves the cycle performance of HE-NCM/graphite full cells and effectively prevents the transition metal dissolution from HE-NCM into electrolytes. Ex-situ surface analysis on HE-NCM and graphite electrodes reveals that the surface chemistry of HE-NCM is not significantly altered with $\mathrm{Al}_{2} \mathrm{O}_{3}$ coating, however, the surface chemistry of graphite is affected significantly. When cycled with the $\mathrm{Al}_{2} \mathrm{O}_{3}$-coated HE-NCM, the surface of graphite is stable over the first 50 cycles, while the surface of graphite cycled with the uncoated HE-NCM has strong features of $\mathrm{LiPF}_{6}$ salt decomposition products and oligo or poly carbonates. The results suggest transition metal dissolution catalyzes additional electrolyte decomposition on the graphite surface. The additional electrolyte decomposition induces the resistance increase of graphite and further affects full cell performance. The improved cycling performance can be attributed to the prevention of transition metal dissolution from HE-NCM resulting in minimized resistance increase on the graphite anode.

\section{Acknowledgments}

The authors gratefully acknowledge funding from the BASF electrochemistry network. There are no conflicts of interest.

\section{ORCID}

Sunhyung Jurng (D) https://orcid.org/0000-0003-0780-0935

Satu Kristiina Heiskanen (1) https://orcid.org/0000-0001-9812-0147

Brett L. Lucht (D) https://orcid.org/0000-0002-4660-0840

\section{References}

1. X. D. Xiang, J. C. Knight, W. S. Li, and A. Manthiram, Journal of Physical Chemistry $C, \mathbf{1 1 8}(38), 21826(2014)$.

2. A. Manthiram, J. C. Knight, S. T. Myung, S. M. Oh, and Y. K. Sun, Advanced Energy Materials, 6(1), (2016).

3. P. K. Nayak, J. Grinblat, E. Levi, B. Markovsky, and D. Aurbach, J. Power Sources, 318, 9 (2016).

4. H. Liu, K. J. Harris, M. Jiang, Y. Wu, G. R. Goward, and G. A. Botton, ACS Nano, 12(3), 2708 (2018).

5. C. Zhan, T. Wu, J. Lu, and K. Amine, Energy Environ. Sci., 11, 243 (2018).

6. T. Joshi, K. Eom, G. Yushin, and T. F. Fuller, J. Electrochem. Soc., 161(12), A1915 (2014).

7. X. Li, M. Xu, Y. Chen, and B. L. Lucht, J. Power Sources, 248, 1077 (2014).

8. H. Zheng, Q. Sun, G. Liu, X. Song, and V. S. Battaglia, J. Power Sources, 207, 134 (2012).

9. D. R. Gallus, R. Schmitz, R. Wagner, B. Hoffmann, S. Nowak, I. Cekic-Laskovic, R. W. Schmitz, and M. Winter, Electrochim. Acta, 134, 393 (2014).

10. N. P. W. Pieczonka, Z. Liu, P. Lu, K. L. Olson, J. Moote, B. R. Powell, and J.-H. Kim, The Journal of Physical Chemistry C, 117(31), 15947 (2013).

11. M. Evertz, F. Horsthemke, J. Kasnatscheew, M. Börner, M. Winter, and S. Nowak, J. Power Sources, 329, 364 (2016).

12. J. Park, J. H. Seo, G. Plett, W. Lu, and A. M. Sastry, Electrochem. Solid-State Lett., 14(2), A14 (2011).

13. M. Wohlfahrt-Mehrens, C. Vogler, and J. Garche, J. Power Sources, 127(1), 58 (2004).

14. C. Zhan, J. Lu, A. Jeremy Kropf, T. Wu, A. N. Jansen, Y. K. Sun, X. Qiu, and K. Amine, Nat Commun, 4, 2437 (2013).

15. C. Delacourt, A. Kwong, X. Liu, R. Qiao, W. L. Yang, P. Lu, S. J. Harris, and V. Srinivasan, J. Electrochem. Soc., 160(8), A1099 (2013).

16. S. Komaba, N. Kumagai, and Y. Kataoka, Electrochim. Acta, 47(8), 1229 (2002).

17. J. Cho, Y. J. Kim, and B. Park, Chem. Mater, 12(12), 3788 (2000).

18. S.-T. Myung, K. Izumi, S. Komaba, H. Yashiro, H. J. Bang, Y.-K. Sun, and N. Kumagai, The Journal of Physical Chemistry C, 111(10), 4061 (2007).

19. D. Mohanty, K. Dahlberg, D. M. King, L. A. David, A. S. Sefat, D. L. Wood, C. Daniel, S. Dhar, V. Mahajan, M. Lee, and F. Albano, Sci Rep, 6, 26532 (2016).

20. X. Huang, K. Chen, and Y. Liu, J. Electrochem. Soc., 166(3), A5081 (2019).

21. Y. J. Kim, J. Cho, T.-J. Kim, and B. Park, J. Electrochem. Soc., 150(12), (2003).

22. D. H. Snydacker, M. Aykol, S. Kirklin, and C. Wolverton, J. Electrochem. Soc., 163(9), A2054 (2016).

23. P. F. Yan, J. M. Zheng, X. F. Zhang, R. Xu, K. Amine, J. Xiao, J. G. Zhang, and C. M. Wang, Chem. Mater, 28(3), 857 (2016).

24. J. A. Gilbert, I. A. Shkrob, and D. P. Abraham, J. Electrochem. Soc., 164(2), A389 (2017).

25. J. Wandt, A. Freiberg, R. Thomas, Y. Gorlin, A. Siebel, R. Jung, H. A. Gasteiger, and M. Tromp, Journal of Materials Chemistry A, 4(47), 18300 (2016).

26. S. Verdier, L. El Ouatani, R. Dedryvere, F. Bonhomme, P. Biensan, and D. Gonbeau, J. Electrochem. Soc., 154(12), A1088 (2007). 
27. X. Zhang, I. Belharouak, L. Li, Y. Lei, J. W. Elam, A. Nie, X. Chen, R. S. Yassar, and R. L. Axelbaum, Advanced Energy Materials, 3(10), 1299 (2013).

28. Y.-C. Lu, A. N. Mansour, N. Yabuuchi, and Y. Shao-Horn, Chem. Mater, 21(19), 4408 (2009).

29. R. Dedryver̀e, S. Laruelle, S. Grugeon, L. Gireaud, J. M. Tarascon, and D. Gonbeau, J. Electrochem. Soc., 152(4), A689 (2005).

30. A. M. Andersson and K. Edstrom, J. Electrochem. Soc., 148(10), A1100 (2001).

31. R. Alcántara, G. F. Ortiz, P. Lavela, J. L. Tirado, W. Jaegermann, and A. Thißen, $J$ Electroanal. Chem., 584(2), 147 (2005).

32. M. Herstedt, D. P. Abraham, J. B. Kerr, and K. Edstrom, Electrochim. Acta, 49(28), 5097 (2004).
33. A. M. Andersson, D. P. Abraham, R. Haasch, S. MacLaren, J. Liu, and K. Amine, $J$. Electrochem. Soc., 149(10), A1358 (2002).

34. S. W. Song, G. V.Zhuang, and P. N. Ross, J. Electrochem. Soc., 151(8), A1162(2004)

35. K. Xu, G. V. Zhuang, J. L. Allen, U. Lee, S. S. Zhang, P. N. Ross Jr., and T. R. Jow, J. Phys. Chem. B, 110(15), 7708 (2006).

36. B. S. Parimalam, A. D. MacIntosh, R. Kadam, and B. L. Lucht, Journal of Physical Chemistry C, 121(41), 22733 (2017).

37. P. Verma, P. Maire, and P. Novak, Electrochim. Acta, 55(22), 6332 (2010)

38. L. Yang, B. Ravdel, and B. L. Lucht, Electrochem. Solid-State Lett., 13(8), A95 (2010).

39. R. Marom, O. Haik, D. Aurbach, and I. C. Halalay, J. Electrochem. Soc., 157(8), A972 (2010).

40. W Li and B. L Lucht, J. Power Sources, 168(1), 258 (2007). 